УДК 351:659.3:316.62

\title{
Соціальна реклама в системі Аержавно-управлінської комунікації
}

\author{
B.M. АРЕШПАК \\ Аніпропетровський регіональний інститут Аержавного управАіння \\ Національної акалемії Аержавного управління при Презилентові України, \\ м. Аніпропетровськ, Україна, E-mail: profil@ua.fm
}

\section{Авторське резюме}

Проаналізовано підходи щодо визначення змісту та функцій соціальної реклами в державно-управлінських комунікаціях. Обгрунтовано можливість вивчення соціальної реклами у державно-управлінських комунікаціях з позицій системного підходу. Досліджено функціонування соціальної реклами у розрізі таких складових комунікативної системи державного управління, як: 1) підсистема суб'єктів комунікації; 2) технологічна підсистема; 3) технічна підсистема; 4) семіотична підсистема. На цій основі виокремлено та проаналізовано: суб'єкти, технології, технічні та семіотичні засоби комунікації в державному управлінні, що відбувається з використанням соціальної реклами. Продемонстровано, що використання такого методологічного підходу дозволить в умовах реального комунікативного простору виявити фактори, що впливатимуть на ступінь ефективності використання соціальної реклами в системі державно-управлінської комунікації.

Ключові слова: комунікація в державному управлінні, соціальна реклама, система державного управління, комунікативна діяльність, засоби масової інформації.

\section{Social advertising in the system of public-administrative communications}

\author{
V. M. DRESHPAK \\ Dnepropetrovsk regional institute of public administration, the National \\ academy of public administration, office of the President of Ukraine, \\ Dnipropetrovsk, Ukraine, E-mail: profi1@ua.fm
}

\begin{abstract}
The approaches of defining the content and functions of social advertising in the system of public-administrative communications had been analyzed. The possibility of investigation of social advertising in public-administrative communications had been substantiated from the position of the system management approach. The functioning of social advertising is examined in terms of such components of communicative systems of public administration as: 1 ) subsystem of communication subjects; 2) technological subsystem; 3) technical subsystem; 4) semiotic subsystem. On this basis the following concepts had been singled out and analyzed: subjects, technologies, technical and semiotic communication in public administration that uses social advertising. It had been demonstrated that using of this methodological approach will allow to identify factors that will influence on the degree of efficiency of using social advertising in the system of public-administrative communications in a real communicative space.
\end{abstract}

Keywords: communication in public administration, social advertising, system of public administration, communicative activity, mass media.

Постановка проблеми. Комунікативною основою державного управління як соціальної за своїм змістом діяльності є сукупність певних форм і способів вза-

(c) B.M. Дрешпак, 2015 
ємодії різних суб'єктів - державних і соціальних інститутів, соціальних груп, окремих індивідів. У цьому контексті державно-управлінська комунікація являє собою взаємні інформаційні впливи суб'єктів владних повноважень один на одного, а також на суб'єктів зовнішнього соціального середовища, 3 метою реалізації наявних владних та управлінських повноважень. При цьому комунікативна діяльність у системі державного управління в сучасних умовах становлення інформаційного суспільства потребує використання комунікативних форм якнайширшого спектра. Лише завдяки цьому, у зв'язку із значним перенасиченням інформаційного простору, можна досягти максимальної ефективності зазначених вище інформаційних впливів, а відтак - мети державно-управлінських комунікацій.

Серед ефективних форм державноуправлінської комунікації в Україні нині дедалі частіше використовується соціальна реклама. При цьому необхідність подальшої модернізації підходів щодо використання соціальної реклами в системі державно-управлінської комунікації за сучасних умов потребує додаткового розкриття окремих актуальних теоретичних і прикладних аспектів роботи 3 нею.

Аналіз досліджень і публікацій. Питання використання соціальної реклами в державному управлінні останнім часом уже знайшли відображення у наукових працях, зокрема дисертаційних дослідженнях низки українських та зарубіжних авторів. Так, Т. Ревенко комплексно дослідила технології соціальної реклами в діяльності органів влади [8], Г. Гулакова розглядала соціальну рекламу як складову інформаційно-мотиваційного механізму державного управління [3], I. Давидкіна вивчала змістовно-функціональні характеристики соціальної реклами, що забезпечують ефективність ї̈ застосування в державному управлінні [4]. Деякі аспекти використання соціальної реклами для вирішення суспільно значущих проблем, зокрема у процесі державного управління, розглядали T. Безверха, В. Бугрим, Є. Ромат,
С. Шубін, автор цієї статті та інші науковці. У такий спосіб розв'язувалися окремі, актуальні для поточного моменту часу проблеми. Проте, системний підхід до вивчення соціальної реклами в державно-управлінських комунікаціях, на наш погляд, дозволить не лише знайти розв'язання виявлених проблем у сфері застосування соціальної реклами в державному управлінні, але й прогнозувати і попереджати потенційні проблеми.

Метою дослідження є обгрунтування методологічного підходу до вивчення соціальної реклами з позиції її функціонування в системі державно-управлінської комунікації в розрізі окремих складових цієї системи.

Виклад основного матеріалу. У комунікативному просторі сучасної людини реклама як така посідає вагоме місце, оскільки за умови перенасичення цього простору найбільш ефективними виявляються повідомлення у формах, що дозволяють нести сконцентроване, «згущене» змістовне наповнення, впливати на людей на позасвідомому рівні. Реклама, впливаючи одночасно на думки та почуття, сприяє формуванню стереотипного мислення, виступаючи потужним інструментом впливу на ціннісні установки й орієнтири цільової аудиторії. Внаслідок цього формуються стереотипні уявлення про певні явища та процеси суспільного життя, що відповідають меті цього рекламного впливу. Завдяки цілеспрямованому впливові на формування ціннісних орієнтацій певної аудиторії шляхом використання реклами можна відповідно спрямовувати поведінку, а відтак, здійснювати управління даною спільнотою.

Ведучи мову саме про соціальну рекламу як один з видів реклами, дослідники та практики постійно стикаються з проблемою виокремлення їі особливих рис. Тому визначення змісту соціальної реклами та її місця в соціальному управлінні у цілому і державному управлінні зокрема різними авторами дещо різняться залежно від обраного ракурсу розгляду цього багатоманітного явища.

Так, за Законом України «Про ре- 
кламу», соціальна реклама - інформація будь-якого виду, розповсюджена в будьякій формі, що спрямована на досягнення суспільно корисних цілей, популяризацію загальнолюдських цінностей i розповсюдження якої не має на меті отримання прибутку. Соціальна реклама не повинна містити посилань на конкретний товар та/або його виробника, на рекламодавця (за винятком випадків, коли рекламодавцем $є$ громадська організація), на об'єкти права інтелектуальної власності, що належать виробнику товару або рекламодавцю соціальної реклами [7]. У такий спосіб законодавець наводить низку формальних ознак, що дозволяють відмежувати соціальну рекламу від комерційної та політичної, хоча на практиці з цим іноді є проблеми.

Акцент щодо спрямованості соціальної реклами на досягнення суспільної корисності спонукає окремих авторів (В. Бугрим, Г. Гулакова, Г. Ніколайшвілі, інші) ототожнювати соціальну рекламу з інструментом соціальної політики (або навіть «необхідним інформаційним відгалуженням соціальної політики держави» $[1$, с. 59]. Щодо цього необхідно зауважити, що насправді спрямування соціальної реклами на досягнення суспільно корисних цілей стосується всіх без винятку галузей державної політики, а мета щодо популяризації загальнолюдських цінностей може обумовлювати їі розгляд як інструмента більшою мірою державної гуманітарної (а не соціальної!) політики, що зосереджена на забезпеченні передусім духовного розвитку суспільства та впливає насамперед на ціннісно-смислову сферу суспільного життя. У контексті розгляду державного управління $з$ позицій комунікативної парадигми соціальну рекламу розглядають як один 3 комунікативних інструментів державного управління.

Так. Г. Гулакова слушно визначає соціальну рекламу як вид рекламної комунікації, мета якої - передача суспільству соціально значущої інформації, спрямованої на формування і зміну громадської думки, соціальних норм, моделей поведінки. Надзавданням цієї кому- нікації є залучення членів суспільства до вирішення соціальних проблем [2].

Т. Ревенко розглядає поняття «соціальна реклама» як специфічну форму соціальної комунікації органів влади та громадських організацій, що не має комерційного характеру, привертає увагу до соціально значущих проблем, спрямована на формування загальнолюдських цінностей і зміну поведінкової моделі суспільства з метою сприяння бажаному розвитку. При цьому соціальна реклама також розглядається як соціальна технологія управлінського типу, оскільки вона викликає зміни в моделі поведінки громадян і суб'єктів господарювання [8, c. 4]. I. Давидкіна визначає соціальну рекламу як різновид соціальних комунікацій, що цілеспрямовано впливають на формування соціально значущих цінностей, сприяють узгодженню інтересів і прагнень різних соціальних груп, виробленню суспільно схвалюваних способів задоволення цих прагнень, забезпечуючи тим самим стабільність суспільної системи в цілому. Соціальна реклама, як слушно зауважує ця авторка, на відміну від комерційної, формує уявлення не про продукт, а про конкретну суспільну проблему, шляхи іiі вирішення, моделі соціально корисної та соціально безпечної поведінки. Таким чином, соціальна реклама містить мотивацію до соціально корисної дії [4, с. 5].

Отже, визначаючи соціальну рекламу як одну 3 форм державно-управлінської комунікації, її неодмінно слід розглядати також і як інструмент державного управління. За допомогою цього інструмента має відбуватися формування уявлень членів суспільства щодо певних соціальних проблем та залучення громадян до участі в подальшому узгодженому вирішенні цих проблем, формування у членів суспільства належних (соціально корисної та соціально безпечної) поведінкових моделей, наслідком чого має бути стабільність даної суспільної системи, реалізація інших впливів. Тобто, у цьому випадку матимемо справу зі зміною поведінки суб'єктів внаслідок комплексного цілеспрямованого інформаційного впливу на цільову 
групу з достатньо чітко визначеною метою зміни поведінки їі представників. Відтак, соціальна реклама $€$ формою державно-управлінської комунікації, призначеної для трансляції певними комунікативними каналами повідомлень, що забезпечують досягнення визначеної мети певного управлінського впливу.

У такий спосіб проявляються основні функції, спільні для всіх видів реклами, та специфічні, притаманні саме соціальній рекламі. Зокрема, як основні функції реклами зазвичай називають інформування, умовляння, нагадування. Серед специфічних функцій соціальної реклами I. Давидкіна виокремлює: інформаційно-просвітницьку; соціально-культурологічну (включно 3 профілактикою антисоціальних явищ, адаптацією громадян до змін в соціально-економічній системі, соціалізацією молоді, збереженням культурних традицій); консолідуючу; зворотного зв'язку (що полягає в узгодженні пріоритетів державної політики та цінностей громадянського суспільства) [4, с. 6]. У цілому з таким підходом можна погодитися з урахуванням того, що в такий спосіб охоплено гносеологічний, онтологічний та аксіологічний аспекти впливу соціальної реклами. Тобто, соціальна реклама $є$ ресурсом для здійснення пізнавальної діяльності, упорядкування буття, коригування ціннісних орієнтацій цільової аудиторії i, таким чином, може бути корисною для вирішення цілого комплексу завдань на різних рівнях соціального (у тому числі й державного) управління.

3 урахуванням спрямування впливу соціальної реклами в системі державно-управлінських комунікацій цілком умотивованим є розподіл соціальної реклами на внутрішньо- та зовнішньо орієнтовану, тобто ту, яка може застосовуватися і у внутрішньо-організаційних, i в зовнішніх комунікаціях. Це обумовлено різними завданнями, що стоять перед комунікаторами у процесі вирішення наявних проблем. Так, Г. Гулакова вказує на наявність двох рівнів проблем, що стоять перед системою державного управління України і які можуть бути подолані за допомогою сучасної соціальної реклами:

- проблеми, пов'язані із забезпеченням ефективності процесу управління;

- проблеми, вирішення яких забезпечується під час управління соціальними процесами [2]. 3 цих позицій можна умовно поділяти соціальну рекламу на ту, що супроводжує безпосередню управлінську діяльність, і ту, що є інструментом цієї діяльності. У будь-якому разі і в першому, і в другому випадках соціальна реклама має бути спрямована на: 1) легітимацію цілі (цінності), що рекламується, як суспільно необхідної, важливої; 2) мотивування аудиторії (внутрішньої або зовнішньої) досягти зазначеної цілі, прийняти (зберегти) зазначену цінність; 3) визначення й легітимацію шляхів і засобів досягнення цілі, набуття (збереження) цінності.

Проте, наведені погляди на соціальну рекламу в системі державно-управлінських комунікацій відображають лише окремі підходи. Більш важливим $€$ формування комплексного бачення функціонування соціальної реклами в державному управлінні за системним підходом. Попередньо здійснений нами структурно-функціональний аналіз комунікативної підсистеми державного управління та комунікативної діяльності в системі державного управління дозволив виокремити чотири притаманні їм основні складові: 1) соціальна складова - це окремі особи та соціальні групи, які $€$ учасниками комунікативної діяльності, джерелами й отримувачами контенту - саме ця складова визначає сутнісні характеристики комунікативної діяльності загалом; 2) технологічна складова - способи та прийоми створення, трансляції, отримання й розуміння, зберігання повідомлень; 3) технічна складова - системи та засоби створення, трансляції, отримання й декодування, зберігання повідомлень; 4) семіотична складова - окремі знаки та знакові системи, які є формою для контенту, його носіями. 3 огляду на викладені позиції, комунікативна підсистема державного управління, на наш погляд, складається з таких підсистем нижчого порядку: 1) 
підсистеми суб'єктів комунікації; 2) технологічної підсистеми; 3) технічної підсистеми; 4) семіотичної підсистеми [5].

Далі розглянемо функціонування соціальної реклами у системі державноуправлінської комунікації (означимо далі цей багатоаспектний процес робочим терміном «соціо-рекламна комунікація у державному управлінні») у розрізі виокремлених вище підсистем. За цим підходом доцільно проаналізувати: суб'єкти, технології, технічні та семіотичні засоби соціо-рекламної комунікації у державному управлінні.

Суб'єктами соціо-рекламної комунікації у державному управлінні $€$ суб'єкти владних повноважень та їх посадові особи, різні соціальні групи, на яких орієнтована ця реклама, організації, які займаються виробництвом та розповсюдженням соціальної реклами. За Законом України «Про рекламу» передбачено особливі умови розміщення соціальної реклами у засобах масової інформації, що повністю або частково фінансуються 3 державного або місцевих бюджетів. Так, вони зобов'язані розміщувати соціальну рекламу органів державної влади та органів місцевого самоврядування, громадських організацій безкоштовно в обсязі не менше п'яти відсотків ефірного часу, друкованої площі, відведених для реклами, а також надавати пільги при розміщенні соціальної реклами, замовниками якої $€$ заклади освіти, культури, охорони здоров'я, які утримуються за рахунок державного або місцевих бюджетів, а також благодійні організації [7]. Отже, Закон стимулює бути рекламодавцями таких суб'єктів як органи державної влади та органи місцевого самоврядування, громадські та благодійні організації, державні та комунальні заклади освіти, культури, охорони здоров'я.

При цьому основним розповсюджувачем соціальної реклами за Законом «призначені бути» державні та комунальні засоби масової інформації. Натомість здебільшого органи державного управління та місцевого самоврядування найчастіше віддають перевагу зовнішній соціальній рекламі (біл-борди, сі- ті-лайти, плакати, транспаранти тощо), за рахунок чого забезпечується тривалий фоновий супровід тематичних інформаційних кампаній у засобах масової інформації. Винятком в останній час $е$ хіба що телевізійна соціальна реклама (у тому числі на недержавних телеканалах) та в мережі Інтернет, створення та поширення якої часто стимулюється шляхом проведення творчих конкурсів тощо. Також чи не найважливішим суб’єктом соціо-рекламної комунікації у державному управлінні $€$ споживачі соціальної реклами. У цьому контексті проблемою забезпечення ефективності соціальної реклами є ї̈ орієнтація на масову свідомість. Проте, щоб бути ефективною, соціальна реклама все ж має носити адресний характер та бути спрямованою на вирішення найважливіших суспільних проблем і ментальні зміни не лише в суспільстві в цілому, а й у конкретній соціальній групі. При цьому групи, на які спрямовано вплив соціальної реклами, можуть виступати як iï «співавтори», визначаючи найбільш актуальні її теми, способи втілення та поширення, особливості інтерпретації. Ретельний аналіз у конкретній ситуації саме цього суб'єкта соціо-рекламної комунікації у державному управлінні обумовлює вибір конкретних технологій та технік соціальної реклами, які б забезпечували досягнення мети конкретного державно-управлінського впливу.

Технології соціо-рекламної комунікації у державному управлінні загалом ми розуміємо як способи та прийоми створення, трансляції, сприйняття й розуміння соціальної реклами, що застосовуються у процесі державно-управлінських комунікацій. Тобто, йдеться про спеціальні комунікативні технології, що можуть застосовуватися саме у сфері соціальної реклами зазначеними вище суб'єктами.

Визначення поняття «технологія соціальної реклами органів влади» подає Т. Ревенко, на думку якої це - сукупність засобів і методів, за допомогою яких здійснюється управлінський влив на соціальну систему, спрямований на формування загальнолюдських 
цінностей і зміну поведінкової моделі суспільства 3 метою сприяння бажаному розвитку [8, с. 4]. Таке визначення відбиває виразно управлінський характер використання соціальної реклами органами влади, проте, на наш погляд, при цьому не слід забувати, що комунікація є двоспрямованим процесом, коли і відправник, і одержувач рекламних повідомлень є однаково важливими суб'єктами, про що вже йшлося вище.

На такій особливості також слушно наголошує й I. Давидкіна, зазначаючи, що комунікативний характер соціальної реклами дозволяє трактувати її учасників як відносно рівноправних суб'єктів соціального простору, кожен з яких конструює реальність з урахуванням своїх можливостей, наявних ресурсів, цінностей, пріоритетів тощо. Відтак, результативність застосування соціальної реклами буде визначатися ступенем збігу уявлень ініціатора та адресата комунікацій щодо актуальності теми рекламного послання та його трактування. За суттєвого розходження соціальна реклама буде зведена до інформування, за умови значного збігу поглядів можливим стає цілеспрямований управлінський вплив $[4$, с. 6].

Наведене свідчить, що вибір конкретної технології соціо-рекламної комунікації у державному управлінні $€$ надзвичайно відповідальним етапом рекламної кампанії та має спиратися на глибоке вивчення цільової аудиторії, а також застосування сучасних способів i прийомів створення і трансляції рекламних повідомлень. На наш погляд, ключовим завданням тут є застосування таких технологій, які забезпечать більш вигідне позиціювання соціальної реклами у комунікативному просторі порівняно з більш агресивними та "просунутими» комерційною i політичною рекламою. Адже на цей час, за нашими оцінками, соціо-рекламна комунікація у державному управлінні здійснюється з використанням переважно традиційних, «м'яких" технологій, завдяки яким, 3 одного боку, споживач дійсно не зазнає «ментальних травм», але 3 іншого ефект такої реклами є занадто низьким, а поставлена мета не досягається.

Технології соціо-рекламної комунікації у державному управлінні $€$ iнтелектуальним продуктом, що поширюється практично без обмежень, тому в плані їх опанування, запозичення, практичного застосування, удосконалення ми не вбачаємо суттєвих перешкод. Відтак, найважливішим поштовхом до більш ефективного застосування та модернізації цих технологій, на наш погляд, має бути добра воля, бажання та необхідні знання й уміння посадових осіб, які займаються цим напрямом діяльності в органах державної влади.

Технічні засоби соціо-рекламної комунікації у державному управлінні ми розглядаємо як сукупність засобів (технічних систем), що використовуються для створення, трансляції, отримання й декодування, зберігання соціальної реклами, що застосовуються у процесі державно-управлінських комунікацій. До таких засобів належать: обладнання для створення поліграфічної, аудіовізуальної продукції; інформаційно-комунікаційна інфраструктура; засоби масової інформації та система їх розповсюдження, носії зовнішньої реклами; технічні засоби для відтворення аудіовізуальних продуктів споживачами; архіви друкованої та аудіовізуальної продукції. Такі засоби не обов'язково мають належати органам державної влади, державним організаціям чи знаходитися в їх управлінні, головне, що вони якнайповніше використовуються у державно-управлінських комунікаціях. Специфіка вибору відповідних технічних засобів також залежить від особливостей аудиторії, на яку орієнтована соціальна реклама (наприклад, особи з вадами слуху та зору або жителі районів з нерозвиненою інформаційно-комунікаційною інфраструктурою). У таких випадках точність обраного засобу трансляції соціальної реклами може бути вирішальною для їі ефективності.

Семіотичними засобами соціо-рекламної комунікації у державному управлінні є окремі знаки та знакові системи, які $\mathrm{e}$ формою для збереження та трансляції змісту рекламних повідомлень 
і застосовуються у процесі державноуправлінських комунікацій. Такими засобами є власне знак, емблема, символ, ïx комплексні поєднання як складні семіотичні форми.

Метою застосування семіотичних засобів під час соціо-рекламної комунікації у державному управлінні $є$ коригування соціопсихологічних спонук діяльності як об'єкта, так і суб'єкта державно-управлінської діяльності. У процесі такої комунікації можуть застосовуватися всі знаки та знакові системи, що входять до відповідної семіотичної підсистеми державного управління i використовуються 3 метою реалізації функцій цієї підсистеми, транслюються відповідними комунікативними каналами в системі державного управління та між нею і зовнішнім середовищем. 3окрема, у соціальній рекламі в державному управлінні часто використовують державні символи (Державний Прапор, Державний Герб, Державний Гімн), символи державної влади (булава, штандарт Президента, будинок державної адміністрації, інше) та символи власне державно-управлінського процесу (проведення наради, підписання указу, вручення державної нагороди тощо).

Важливість точного добору та використання семіотичних засобів соціальної реклами в державному управлінні зумовлена, зокрема, тим, що вплив цієі реклами має бути не лише ментально глибинним, але й тривалим. Як слушно наголошує Е. Мамонтова, коли повідомлення виражене текстуально, а його автором виступає суб'єкт влади, то результатом є безпосередній i, як правило, короткочасний вплив на реципієнта. Значно більш відчутним $є$ ефект від непрямого впливу через створення ідеаль- них образів реальності. Через поєднання вербальної інформації з візуальними та поведінковими формами можливе формування колективних уявлень і переконань i, як наслідок, - управління поведінкою соціуму [6, с. 136 - 137].

Також на вибір семіотичних засобів соціальної реклами нині відчутно впливає тенденція до максимального спрощення рекламних повідомлень в умовах «стиснутого» інформаційного часу та простору, про що ми вже зазначали вище. Вирішальний вплив на споживача часто має виразне зображення, короткий, але змістовно глибокий слоган, відома і зрозуміла багатьом емблема тощо.

Висновки. Вивчення соціальної реклами у системі державно-управлінської комунікації з позицій системного підходу дозволяє розглянути їі функціонування у розрізі таких окремих складових цієї системи, як: 1) підсистема суб'єктів комунікації; 2) технологічна підсистема; 3) технічна підсистема; 4) семіотична підсистема. Відповідно можуть бути виокремлені та проаналізовані: суб'єкти, технології, технічні та семіотичні засоби соціо-рекламної комунікації у державному управлінні. Використання такого методологічного підходу дозволить в умовах реального комунікативного простору виявити фактори, що впливатимуть на ступінь ефективності використання соціальної реклами у системі державно-управлінської комунікації.

Перспективним напрямом досліджень за цією тематикою може бути вивчення практики використання соціальної реклами окремими органами публічної влади в Україні та за рубежем для вирішення окремих комунікативних завдань у процесі державного управління.

СПИСОК АІТЕРАТУРИ:

1. Бугрим В. Соціальна реклама в інформаційному суспільстві / В. Бугрим // Актуальні проблеми міжнародних відносин. - 2004. - № 50. - С. $58-62$.

2. Гулакова Г. В. Моделі ефективності соціальної реклами в процесі реалізації управлінських рішень: шляхи використання / Г.В.Гулакова // Державне управління: удосконалення та розвиток : електрон. наук. фахове вид. - 2012. - № 12 [Електронний ресурс]. - Режим доступу : http://www.dy.nayka.com.ua/?op=1\&z=514

3. Гулакова Г. В. Соціальна реклама як складова інформаційно-мотиваційного механізму державного управління : автореф. дис. на здобуття наук. ступеня канд. наук з держ. упр. : 25.00 .02 - механізми державного управління / Ганна В'ячеславівна Гулакова. - Донецьк, 2013. -20 c. 
4. Давыдкина И. Б. Социальная реклама в государственном управлении : автореф дисс. на соискание науч. степени канд. социол. наук; 22.00.08 - социология управления / Давыдкина Ирина Борисовна. - Волгоград, 2009. - 20 с.

5. Дрешпак В. М. Структура та функції комунікативної підсистеми державного управління / В. М. Дрешпак // Грані. - 2012. - № 10. - С. 120 - 124.

6. Мамонтова Э. В. Публичное управление как политико-коммуникативный процесс: символический аспект / Э. В. Мамонтова // Вісник Дніпропетровського ун-ту. - Серія «Політологія». - Д. : ДНУ, 2013. - Т. 20. - Вип. 23 (3). - С. $135-140$.

7. Про рекламу : Закон України від 03.07.1996 р. № 270/96-ВР; зі змінами станом на 03.10.2014 p. - Режим доступу : http://zakon4.rada.gov.ua/laws/show/270/96$\% \mathrm{D} 0 \% \mathrm{~B} 2 \% \mathrm{D} 1 \%$ 80/page

8. Ревенко Т. В. Технології соціальної реклами в діяльності органів влади : автореф. на здобуття наук. ступеня канд. наук. з держ. упр.; 25.00.02 - механізми державного управління / Ревенко Тетяна Вікторівна. - Х., 2012. - 20 с.

\section{REFERENCES:}

1. Buhrym V. Sotsial'na reklama v informatsiynomu suspil'stvi (Social advertising in the information society) // Aktual'ni problemy mizhnarodnykh vidnosyn. -2004 . - № 50. - P. $58-62$.

2. Hulakova H. $V$. Modeli efektyvnosti sotsial'noyi reklamy v protsesi realizatsiyi upravlins'kykh rishen': shlyakhy vykorystannya (Models effectiveness of social advertising in the implementation of management decisions: ways of use) // Derzhavne upravlinnya: udoskonalennya ta rozvytok : elektron. nauk. fakhove vyd. - 2012. - № 12. - Mode of access : http://www.dy.nayka. com.ua/ $\mathrm{op}=1 \& \mathrm{z}=514$

3. Hulakova H. V. Sotsial'na reklama yak skladova informatsiyno-motyvatsiynoho mekhanizmu derzhavnoho upravlinnya : avtoref. dys. na zdobuttya nauk. stupenya kand. nauk z derzh. upr. : 25.00.02 - mekhanizmy derzhavnoho upravlinnya (Social advertising as part of informationmotivational mechanism of governance: Author. Thesis. on competition sciences. degree candidate. Sciences of state. Exercise. : 25.00.02). - Donets'k, 2013. - 20 p.

4. Davyidkina I. B. Sotsialnaya reklama v gosudarstvennom upravlenii : avtoref diss. na soiskanie nauch. stepeni kand. sotsiol. nauk; 22.00.08 - sotsiologiya upravleniya (Social advertising in public administration: Abstract diss. on competition of a scientific. PhD degree. sotciol. Sciences). - Volgograd, 2009. - 20 p.

5. Dreshpak V. M. Struktura ta funktsiyi komunikatyvnoyi pidsystemy derzhavnoho upravlinnya (Structure and function of communication subsystem of public administration)// Hrani. -2012 . - № 10. - P. $120-124$.

6. Mamontova E. V. Publichnoe upravlenie kak politiko-kommunikativnyiy protsess: simvolicheskiy aspekt (Public administration as a politico-communicative process: the symbolic aspect) // VIsnik DnIpropetrovskogo un-tu. - SerIya "PolItologIya". - D. : DNU, 2013. - Vol. 20. - Vip. 23 (3). - P. $135-140$.

7. Pro reklamu : Zakon Ukrayiny vid 03.07.1996 r. № 270/96-VR; zi zminamy stanom na 03.10.2014 r. (On Advertising: Law of Ukraine of 07.03.1996 p. № 270/96-BP; amended as of 03/10/2014). - Mode of access : http://zakon4.rada.gov.ua/laws/show/270/96$\%$ D0 $\%$ B2 $\%$ D1 $\%$ 80/page

8. Revenko T. V. Tekhnolohiyi sotsial'noyi reklamy v diyal'nosti orhaniv vlady : avtoref. na zdobuttya nauk. stupenya kand. nauk. z derzh. upr.; 25.00.02 - mekhanizmy derzhavnoho upravlinnya (Technology PSAs in the activities of the authorities: Author. on competition sciences. degree candidate. Science. with the state. Exercise .; 25.00 .02 - mechanisms of public administration). - Kh., 2012. $-20 \mathrm{p}$.

Дрешпак Валерій Михайлович - доктор наук з державного управління, доцент Дніпропетровський регіональний інститут державного управління Національної академії державного управління при Президентові України

Адреса: 49044, м. Дніпропетровськ, вул. Гоголя, 29

E-mail: profi1@ua.fm

Dreshpak Valerij Mykhaylovych - doctor of public administration, associate professor Dnepropetrovsk regional institute of public administration, the National academy of public administration, office of the President of Ukraine

Address: 29, Gogol Str., Dnipropetrovsk, 49044, Ukraine

E-mail:profi1@ua.fm 